\title{
Foreign Direct Investment Attractiveness of Central, Eastern, and Southeastern European Countries: The Importance of Policy-Related Location Advantages
}

\section{Svilena Mihaylova}

University of Economics - Varna, Bulgaria

s.mihaylova@ue-varna.bg

\author{
CroEconsur \\ Vol. 22 \\ No. 1 \\ June 2020 \\ pp. 65-101
}

Received: December 13, 2019

Accepted: May 5, 2020

Research Article

doi:10.15179/ces.22.1.3

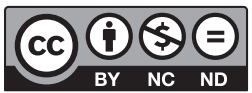

\section{Abstract}

The paper aims to enhance the discussion about foreign direct investment (FDI) attractiveness of Central, Eastern, and Southeastern European (CESEE) countries, by focusing on those location determinants of FDI which fall within the scope of public policy. First, we summarize the literature on location advantages. Second, some general trends in FDI inflows to the CESEE region are outlined. Third, based on data for 15 CESEE countries in 2013 and 2017, we build a composite index, which allows us to rank countries in terms of their FDI attractiveness, as well as its most important policy-related dimensions, such as institutional framework, infrastructure endowment, labor force quality, and cost competitiveness. In addition to allowing comparison between economies across these dimensions, the 
results reveal areas in which some countries need improvement so that they can attract more FDI.

Keywords: foreign direct investment, public policy, economic comparison, composite index

JEL classification: F21, H11, O57, C43

\section{Introduction}

Since the outset of the economic transformations in Central, Eastern, and Southeastern Europe (CESEE), foreign direct investment (FDI) has been regarded as a source of significant benefits to the host countries such as financing capital formation, enterprise restructuring, transfer of technology, knowledge and skills, job creation, productivity spillovers, enhanced competition, and improved access for exports into foreign markets (Holland, Sass, Benacek, \& Gronicki, 2000; Botrić \& Škuflić, 2006; Kalotay, 2010). These expectations induced many of the transition economies in CESEE to adopt investor-friendly policies, with the hope to attract FDI and boost their economic development.

The inward FDI stock in the CESEE region is substantial (USD 838 billion in 2017 according to UNCTAD) and reflects a high level of foreign capital penetration. However, countries' progress in attracting FDI has been rather uneven, since more than half of the inward FDI stock in the region in 2017 was concentrated in just three countries (Poland, the Czech Republic, and Hungary). This raises the question about CESEE countries' location advantages and especially those which can be influenced by public policy.

Although there is growing literature on FDI in transition economies, there has been relatively little research on FDI in the SEE countries (Estrin \& Uvalic, 2014). Hence, the paper complements the literature on FDI determinants in transition economies by exploring FDI attractiveness in a group of four SEE countries (Albania, Montenegro, Serbia, and Bosnia and Herzegovina) and 
11 EU member countries from CEE (Bulgaria, Croatia, the Czech Republic, Estonia, Hungary, Latvia, Lithuania, Poland, Romania, Slovakia, and Slovenia). Together they represent a unique context for analysis of the determinants of FDI due to two reasons. First, as post-socialist economies, they share similar historical background, which provides a high level of comparability for the analysis. Second, FDI was absent under the system of central planning in these countries but afterwards played an important role in their transition to market-based economies. While most studies on FDI determinants use regression analyses, the present paper constructs a composite FDI index, which allows comparing countries in terms of their FDI attractiveness, as well as its key policy-related dimensions - institutional framework, infrastructure endowment, labor force quality, and cost competitiveness. The index is calculated for two years (2013 and 2017) to allow comparison.

The rest of the paper is structured as follows: Section 2 reviews the literature on the location determinants of FDI. Section 3 outlines the main trends in inward FDI in CESEE countries. Section 4 describes the data and methodology used. Section 5 presents the results from the analysis and the last section draws conclusions.

\section{Literature Review}

Instead of offering a single unifying theory, the literature on FDI presents a variety of theoretical models attempting to explain FDI and the location decisions of MNEs (Faeth, 2009). Since the review of all theories regarding the determinants of FDI is beyond the scope of this paper, for the purpose of the research the focus is put on the location advantages of host countries as part of the OLI framework, developed by Dunning (1979, 1988). Due to its complex nature, the OLI paradigm is the most widely used framework for empirical analysis of FDI determinants. The eclectic theory of Dunning combines ownership (O), location (L), and internalization (I) advantages as determinants of FDI, which were previously discussed in separate theories. Ownership advantages refer to 
the competitive advantages of MNEs over domestic firms and include superior technology, management and organizational skills, patents, reputation, etc. Location advantages refer to the country-specific advantages that the MNE gains when investing abroad and include access to markets and resources, lower labor costs, favorable tax system, lower risk, government policy which is conducive for FDI, etc. Internalization advantages relate to the benefits that the MNE may obtain if it engages in foreign production itself rather than licensing the right to do so. Such benefits include cutting transaction costs, minimizing technology imitation, and sustaining the MNE's reputation through effective management and quality control.

Throughout its history, OLI has evolved from a theory of international production to a much more complex paradigm. According to Eden (2003) and Narula (2010), it has gone through several stages. Starting in the 1970s as a theory focused on the determinants of international production, throughout the 1980s and 1990s the eclectic paradigm was deepened in several ways - responding to criticisms by internalization theorists (Dunning, 1988), incorporating a dynamic element by putting forward the "investment development path" (Dunning, 1981), applying to different industries (Dunning, 1988, 1993a), and broadening the location component (Dunning, 1988, 1993a, 1997). Next, prompted by the growing use of cooperative agreements, Dunning (1993a, 1993b) added the concept of alliance capitalism. In response to the emergence of international strategic management, Dunning (1993a) also attempted to incorporate strategy. In its latest version, the paradigm has been expanded to include institutional factors more systematically (Dunning \& Lundan, 2008a).

While the OLI paradigm has been constantly expanded in order to stay relevant, some scholars argue that it has also become too broad and cumbersome (Narula, 2010). Nevertheless, the contributions of the OLI paradigm are irrefutable, especially when it comes to the location of MNEs. 
Dunning's original formulation of the location advantage was a simple list of country-specific characteristics which attract MNEs (Dunning, 1979). They included the spatial distribution of inputs and markets; prices, quality, and productivity of inputs; transport and communication costs; government intervention and policies; infrastructure; psychic distance; and scale economies. Later, these location advantages were grouped (Dunning, 1993b) into the ESP paradigm: environment (resources, stage of economic development, cultural/ historic background), system (institutional framework), and policies (general and FDI policies). In his subsequent works in the 2000s, Dunning continued to emphasize the significance of location. Increasing attention has been given to the role of "created assets", which relative to conventional "natural assets" like raw materials or cheap labor, have become more important (Narula \& Dunning, 2000). Among them, institutional development has been outlined as particularly significant for the location decisions of MNEs (Dunning, 2008a, 2008b, 2009).

When discussing the role of institutions, Dunning (2008a, 2008b) builds on North (1990), where institutions are defined as formal rules (constitutions, laws, and regulations) and informal constraints (norms of behavior, conventions, and self-imposed codes of conduct). Institutions are important because they provide the rules of the game of a market economy, allowing lower transaction and information costs and reducing uncertainty (North, 1990). Dunning (2008b) emphasizes that a host country's FDI attractiveness is significantly influenced by its institutional framework because formal institutions enforce property rights, promote good governance, support competition, encourage innovation and entrepreneurship, and facilitate efficient capital markets, while traditions and values promote trust and cooperative behavior. Other studies, such as Peng, Wang, and Jiang (2008), assert that the institutional constraints in the host country, which may be different from those in the home country, influence MNEs' strategic choices. Likewise, Cantwell (2009) treats institutional distance as an especially important constraint on the organization of business across national boundaries. In addition to influencing firms' location choices and strategies, the 
institutional setting also has a profound impact on businesses' operation and performance (North, 1990; Dacin, Goldstein, \& Scott, 2002). Hence, a sound "investor friendly" institutional environment is often perceived as a necessary condition for FDI attraction, whereas poor institutional quality increases the costs of investment and discourages FDI.

The literature review proceeds with outlining the empirical studies on CESEE by grouping them into four categories - institutional framework, infrastructure endowment, labor force quality, and cost competitiveness. They all have proved to be important location determinants of FDI, which at the same time can be potentially influenced by government actions.

\subsection{Institutional Framework}

Empirical studies on the location determinants of FDI in CESEE countries strongly establish the importance of institutional quality. Altomonte (2000) uses panel data techniques to study the FDI determinants in ten CEE countries during the 1989-1996 period. The results show that the design of an efficient, transparent, and enforceable institutional framework (measured by the expected uncertainty of MNEs) in CEE countries is a crucial determinant of FDI. Bevan, Estrin, and Meyer (2004) conduct regression analysis on data for 12 CEE countries in the 1994-1998 period and find that FDI is positively related to several institutional changes: development of private-owned businesses and banking sector, liberalization of foreign exchange and trade, and development of legal institutions. Mateev (2009) uses panel data econometric analysis to explore traditional and transition-specific determinates of FDI in Central and Southeastern Europe and finds a negative relationship between corruption (one of the aspects of institutional stability) and FDI inflows. In a study on seven SEE countries, Fabry and Zeghni (2010) explore the relationship between inward FDI and institutional arrangement, measured by a global governance index, comprising six indicators: voice and accountability, political stability and 
absence of violence/terrorism, government effectiveness, regulatory quality, rule of law, and control of corruption. The results reveal two institutional profiles: the first one includes Bulgaria, Romania, and Croatia, where the institutional arrangement attracts FDI, whereas the second one, comprising the other SEE countries, is characterized by weaker institutions and needs improvement. The need to improve the institutional quality in SEE countries is also emphasized in Bellak, Leibrecht, and Liebensteiner (2010). In a study of FDI determinants in six CEE countries, Tintin (2013) applies the panel OLS method with fixed effects and shows the positive and significant impact of institutions (measured by economic freedom, state fragility, political rights, and civil liberties indices) on FDI inflows. Dauti (2015) examines FDI determinants in five SEE and ten CEE countries, using both static and dynamic panel models, and concludes that institutional factors like control of corruption, regulatory quality, political risk, and corruption perceptions index, significantly determine inward FDI stock.

\subsection{Infrastructure Endowment}

It is well established that the availability of developed infrastructure is necessary for the operations of MNEs because it lowers distribution, transportation, and production costs, thereby affecting the comparative and absolute advantage of the host country (Mateev \& Tsekov, 2014). Infrastructure comprises transport, energy, and information and communications technology (ICT) infrastructure. As noted by Bellak, Leibrecht, and Liebensteiner (2010), the public sector is responsible for the provision of a substantial part of a country's infrastructure. Even when private agents supply the infrastructure, at least the decision making and the financing are largely within the public sector. Therefore, a significant part of the infrastructure endowment is under the influence of public policy.

In a study of FDI determinants in seven SEE countries, Botrić and Škuflić (2006) find that ICT infrastructure, defined as the number of telephone lines per 100 inhabitants or the number of internet connections, has a positive influence on 
FDI stock. In a panel econometric analysis on eight CEECs for the 1995-2004 period, Bellak, Leibrecht, and Damijan (2009) find that telecommunication and transport infrastructure are of special significance to FDI. Bellak, Leibrecht, and Stehrer (2010) examine four CEE countries over a time span of ten years and find that a higher ICT infrastructure endowment leads to an increase in FDI. In another study, Bellak, Leibrecht, and Liebensteiner (2010) explore the scope for public policy to attract FDI in nine SEE countries and conclude that in order to attract FDI in high value added activities, these countries need to improve their infrastructure endowment. In a research on the spatial interrelationships in FDI in eight CEE countries, Leibrecht and Riedl (2014) use as a control variable a proxy for a country's endowment with production-related material infrastructure, comprising telecommunication, electricity, and transport production facilities. They find that a one-point change in the infrastructure index results in an increase in FDI flows by about 55 percent. In a more recent study on ten CEE countries, Stack, Ravishankar, and Pentecost (2017) also confirm that the development of a modern and efficient physical infrastructure is an essential policy instrument towards achieving potential FDI.

\subsection{Labor Force Quality}

According to the literature, there is a strong positive relationship between FDI and the level of educational attainment in the host economy. Better educated and skilled labor force yields higher returns, thereby attracting more MNEs.

In a study on seven Eastern European countries in the 1993-1999 period, Carstensen and Toubal (2004) find that labor force education, as measured by the fraction of skilled labor to total labor, has a strong positive impact on FDI inflows. Dauti (2015) explores the determinants of FDI in five SEE and ten CEE countries and finds a positive and significant effect of schooling, measured by tertiary school enrolment, on FDI stock. Brahim and Dupuch (2016) compare FDI determinants in EU-15 and CEE countries over the 1993-2010 period. 
Their econometric analysis reveals a positive and significant impact of the education variable (the share of the active population with upper secondary or tertiary education attainment) on FDI inflows. The importance of skilled labor for CEE countries is confirmed by Stack et al. (2017), who conclude that in the longer term, attracting top quality FDI requires policies that develop specialized human capital activities as a complement to an already well-educated and skilled workforce. Using a panel ARDL model, Su et al. (2018) find a significant longrun relationship between FDI and the labor force with advanced education in Poland, the Czech Republic, and Slovakia.

\subsection{Cost Competitiveness}

The cost competitiveness of a country, in terms of lower corporate taxes and labor costs, is considered important by MNEs, especially those that have efficiency-seeking motives. The impact of corporate tax rates on FDI is rather straightforward and well established in the literature. Since the increase in tax rates applied to corporate profits lowers FDI returns, it is expected to discourage inward FDI. In a study on eight CEE countries, Bellak, Leibrecht, and Riedl (2008) find that the reduction of corporate tax rates has a positive impact on FDI flows. Bellak, Leibrecht, and Stehrer (2010) also reveal that lower average effective tax on corporate profits is associated with higher FDI. Similar results can be found in Leibrecht and Riedl (2014). The panel data analysis of Mateev and Tsekov (2014) also confirms the importance of corporate taxes as a location determinant of FDI in CEE countries. In a study of the interaction effects between taxes and infrastructure in eight CEE countries, Bellak et al. (2009) show that in the short run, low corporate income taxes can compensate to some extent MNEs for a lack of sufficiently developed infrastructure endowment. However, in the medium to the long run, these countries should improve their infrastructure endowment in order to make FDI sustainable. In another study, Bellak, Leibrecht, and Liebensteiner (2010) conclude that most SEE countries are already competitive in terms of taxation, which makes this policy instrument 
largely exhausted as a means to attract FDI and requires improvement in other areas such as institutional environment and infrastructure.

As taxes, labor costs partly reflect the extent to which the location decisions of MNEs are driven by efficiency considerations. Rising labor costs imply higher production costs and thus lower FDI. It has to be noted that although labor costs are usually determined by negotiations between employers and employees, the proxies used in the literature to measure labor costs most often include also non-wage labor costs (Bellak, Leibrecht, \& Stehrer, 2010). This makes labor costs, along with the above-described location factors, a variable which can be potentially influenced by public policy.

In a study of FDI determinants in ten CEE countries during the 1989-1996 period, Altomonte (2000) finds that FDI depends on the relative comparative advantage of CEE in terms of labor costs. Bevan and Estrin (2004) use a panel dataset for 11 CEE countries in the 1994-2000 period and find that unit labor costs are negatively associated with FDI, showing that foreign investors are cost sensitive. In another study on 12 CEE countries in the 1994-1998 period, Bevan et al. (2004) conclude that FDI is significantly higher between countries where the relative unit labor cost advantages of relocation are greater. Carstensen and Toubal (2004) find that lower relative unit labor costs increase FDI inflows to CEE countries. Bellak et al. (2008) examine data on eight CEE countries for the 1995-2003 period and find that higher unit labor costs as well as higher total labor costs affect FDI negatively. Mateev (2009) also finds a negative relationship between labor costs and FDI inflows to the countries in Central and Southeastern Europe. Günther and Kristalova (2016) examine FDI determinants in 14 CEE countries in the 1994-2013 period and show that countries which are more successful in attracting FDI have low labor costs. In a more recent study, Stack et al. (2017) find that maintaining relatively low wage and taxation rates is crucial to attracting more FDI. 
In addition to the econometric research, there are some studies which examine FDI determinants by building composite measures of FDI attractiveness of CESEE countries. For example, Popovici and Călin (2012) compute a public policy index, which ranks ten CEE countries in terms of their FDI attractiveness designed by policy makers. The index comprises four sub-indices: infrastructure endowment, institutions' quality, labor market conditions, and level of taxation. A similar approach is undertaken in a report prepared for the European Commission by Copenhagen Economics (2016). It uses data on some of the main policy drivers of FDI and scores 44 non-EU and EU members in terms of their FDI attractiveness. The report selects 18 key indicators, which are used to calculate four sub-indices: political, regulatory, and legal environment; infrastructure and market access; knowledge and innovation capacity; and cost competitiveness. However, as the study of Popovici and Călin (2012), the report does not include the non-EU member states from SEE. Groh and Wich (2012) also build a composite measure of FDI attractiveness, but they use a sample of 127 countries, i.e., they do not focus exclusively on CESEE countries. Moreover, they include a wider range of socioeconomic determinants of FDI and not just those that are under the influence of public policy.

Based on the literature review, it can be concluded that while most studies undertake regression analysis to explore FDI determinants and focus predominantly on CEE, fewer studies use composite indices to rank countries in terms of their FDI attractiveness. Moreover, these studies do not focus exclusively on the countries from CESEE, as the present paper aims to do.

\section{FDI Patterns in CESEE Countries}

The collapse of socialism and the start of liberalization in transition economies offered ample opportunities to foreign investors. FDI inflow to CEE countries accelerated in the second half of the 1990s, reaching USD 24.2 billion in 2000. In the first decade of market transition, Hungary, Poland, and the Czech Republic 
were the leaders in FDI attraction due to their good reform performance. In terms of FDI inflow per capita in this period, Estonia was third (after Hungary and the Czech Republic), followed by Slovakia. This was due to the early adopted liberal course in the economic policy of Estonia. In 2003, there was a drop in FDI inflow in CEE, which was largely due to the end of privatization in the Czech Republic and Slovakia. Between 2003 and the onset of the global economic crisis in 2007-2008, FDI inflow in CEE experienced a steep increase, reaching USD 72.3 billion. During this period, Bulgaria and Romania emerged as significant destinations for FDI. The global economic crisis led to a reduction in FDI inflow, which severely affected all CEE countries and FDI inflow to the region still has not reached its pre-crisis level.

Figure 1: Total Inward FDI Flow in CESEE Countries (in millions of USD)

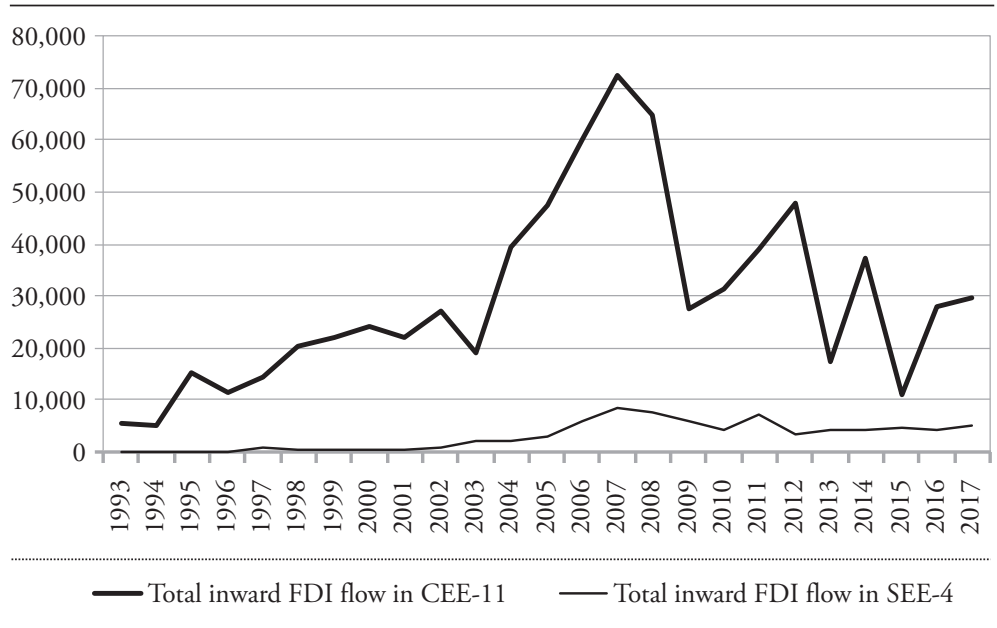

Source: Author's calculations based on data from UNCTAD.

Compared to CEE, foreign investors arrived later to most Western Balkan countries in Southeastern Europe, including Albania, Bosnia and Herzegovina, Montenegro, and Serbia (referred to as SEE-4). As seen in Figure 1, the inward FDI flow to SEE-4 until 2002 was negligible and amounted to an annual average 
of just USD 363 million. This could be attributed to a combination of factors - political and economic instability, military conflicts, ethnic struggle, delay in transition, as well as the smaller size and the greater distance of these economies from Western Europe. There has been a significant increase in FDI inflow to SEE-4 after 2003 and in 2007, before the outbreak of the global economic crisis, it reached USD 8.4 billion. This reflects the efforts of these countries to attract foreign investors' interest.

The accumulated inward FDI stock as a share of GDP is substantial in many of the CESEE countries, which reflects significant foreign capital penetration in their economies. As Figure 2 shows, in 2017 it is the highest in Montenegro (116 percent), Estonia (89 percent), Serbia (86 percent), and Bulgaria (84 percent). For the Balkan countries, the high value of this indicator also reflects the smaller size of their economies. In terms of inward FDI stock per capita, Estonia ranks first, followed by the Czech Republic, whereas Bosnia and Herzegovina and Albania occupy the last two places.

Figure 2: Inward FDI Stock in CESEE Countries, 2017

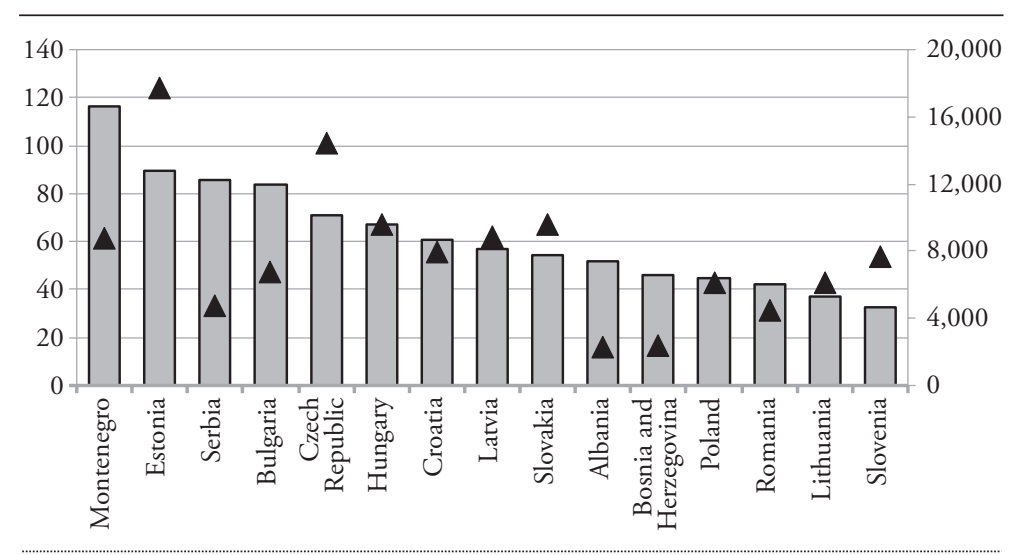

$\square$ FDI stock as a share of GDP (\%) - left axis

$\Delta$ FDI stock per capita (US dollars) - right axis

Source: UNCTAD. 
A specific feature of inward FDI stock in the CESEE region is its very uneven distribution between the host countries. As seen in Figure 3, in 2017 Poland, the Czech Republic, Hungary, and Romania had the highest shares and together accounted for 68 percent of total inward FDI stock in the CESEE region. Conversely, the shares of Bosnia and Herzegovina, Albania, and Montenegro were around 1 percent each.

Figure 3: Distribution of Inward FDI Stock in the CESEE Region, 2017

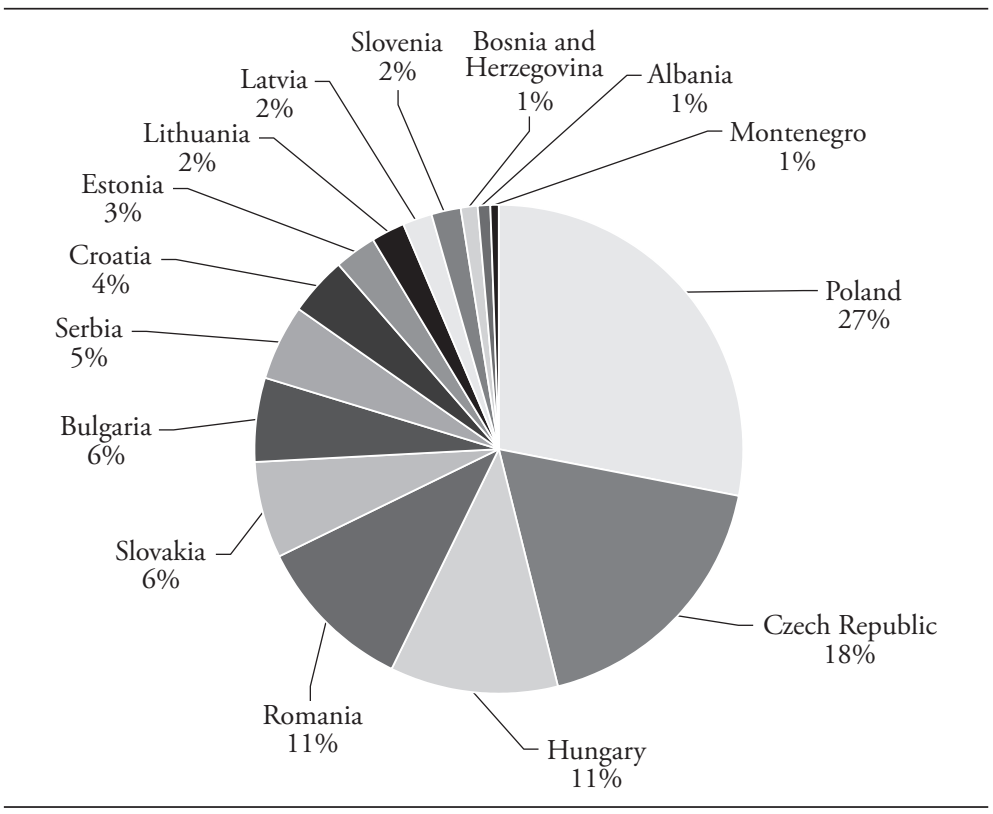

Source: Author's calculations based on data from UNCTAD.

Inward FDI has played an important role in supplementing domestic savings in the transition economies and thus has significantly contributed to the capital formation in the CESEE region. Over the 2008-2016 period, the average share of FDI inflows in gross fixed capital formation has been the highest in Montenegro (70 percent), Albania (30 percent), and Serbia (30 percent). In contrast, the average share of FDI inflows in gross fixed capital formation in CEE-11 was 12 
percent over the same period. The more important role of FDI in the Balkan countries, compared to CEE, could be attributed to their low domestic savings and investment rates. Among the new EU members, FDI contribution to gross fixed capital formation was particularly high in Bulgaria and Estonia (21 percent and 20 percent, respectively).

Based on the briefly described FDI patterns in the CESEE region, it could be concluded that there is substantial variation in the host economies' FDI attractiveness. Given the key role of FDI for economic development, it is important to examine those CESEE host countries' characteristics which serve as location determinants of FDI and are at the same time under the potential influence of public policy.

\section{Data and Methodology}

To analyze the FDI attractiveness of CESEE economies, the study composes an FDI attractiveness index, using data on 15 countries: 11 EU members (Bulgaria, Croatia, the Czech Republic, Estonia, Hungary, Latvia, Lithuania, Poland, Romania, Slovakia, and Slovenia) and four candidate and potential candidate countries (Albania, Montenegro, Serbia, and Bosnia and Herzegovina). To allow for comparison over time, the composite index is calculated for two years - 2013 and 2017.

Composite indicators are used to summarize a number of underlying indicators. Since they measure multi-dimensional concepts, composite indicators are easier to interpret than trying to find a trend in many separate indicators. They are used to rank countries in terms of performance and assess their progress on complex issues over time. Therefore, composite indicators are increasingly recognized as a useful tool in policy analysis (Nardo et al., 2005).

The FDI attractiveness index in this study is constructed around four subindices. They reflect aspects of host countries' investment climate which have 
been outlined in the literature as important location advantages and are at the same time under the influence of public policy. The four sub-indices are institutional framework, infrastructure endowment, labor force quality, and cost competitiveness. To proxy institutional framework, four commonly used variables are selected - investment freedom, business freedom, property rights, and corruption perceptions index. Infrastructure endowment is measured by three indices from the Global Competitiveness Report - transport infrastructure, electricity and telephony infrastructure, and ICT use. To account for labor force quality, the following variables are used: tertiary education enrolment rate, quality of the education system, quality of scientific research institutions, and university-industry collaboration in R\&D. Finally, the cost competitiveness subindex is composed by taking into account corporate income tax, labor tax and contributions, and gross average monthly wages. The variables' description and data sources are given in Table 1 . Some of the variables used to calculate the four sub-indices represent raw data, while others are ready-made indices. The selection of variables is based on data availability for the chosen country sample and time span, as well as on their ability to measure the analyzed location determinants of FDI.

Table 1: List of Variables, Sub-indices and Data Sources

\begin{tabular}{l|l|l}
\hline Variable & \multicolumn{1}{c}{ Description } & Source \\
\hline & $\begin{array}{l}\text { Sub-index 1. Institutional framework } \\
\text { investment freedom). It evaluates a variety of restrictions } \\
\text { typically imposed on investment, including: national } \\
\text { treatment of foreign investment, foreign investment } \\
\text { code, restrictions on land ownership, sectoral investment } \\
\text { restrictions, expropriation of investments without fair } \\
\text { compensation, foreign exchange controls, and capital } \\
\text { freedom } \\
\text { controls. }\end{array}$ & $\begin{array}{l}\text { Index of Economic } \\
\text { Freedom, Heritage } \\
\text { Foundation }\end{array}$ \\
$\begin{array}{l}\text { Business } \\
\text { freedom }\end{array}$ & $\begin{array}{l}\text { Index ranging from 0 (no business freedom) to 100 (total } \\
\text { business freedom). It is a quantitative measure of the ability to } \\
\text { start, operate, and close a business that represents the overall } \\
\text { burden of regulation as well as the efficiency of government in } \\
\text { the regulatory process. }\end{array}$ & $\begin{array}{l}\text { Index of Economic } \\
\text { Freedom, Heritage }\end{array}$ \\
Foundation \\
\hdashline $\begin{array}{l}\text { Property } \\
\text { rights }\end{array}$ & $\begin{array}{l}\text { Index ranging from 0 (lowest property rights protection) to } \\
\text { 100 (highest property rights protection). It is an assessment } \\
\text { of the ability of individuals to accumulate private property, } \\
\text { secured by clear laws that are fully enforced by the state. }\end{array}$ & $\begin{array}{l}\text { Index of Economic } \\
\text { Freedom, Heritage }\end{array}$ \\
Foundation
\end{tabular}




\begin{tabular}{|c|c|c|}
\hline $\begin{array}{l}\text { Corruption } \\
\text { perceptions } \\
\text { index }\end{array}$ & $\begin{array}{l}\text { Index ranging from } 0 \text { (highly corrupt) to } 100 \text { (very clean). } \\
\text { It ranks countries and territories by their perceived levels } \\
\text { of public sector corruption according to experts and } \\
\text { businesspeople. }\end{array}$ & $\begin{array}{l}\text { Transparency } \\
\text { International }\end{array}$ \\
\hline \multicolumn{3}{|c|}{ Sub-index 2. Infrastructure endowment } \\
\hline $\begin{array}{l}\text { Transport } \\
\text { infrastructure }\end{array}$ & $\begin{array}{l}\text { Index measuring the quality of overall infrastructure, roads, } \\
\text { railroad infrastructure, port infrastructure, air transport } \\
\text { infrastructure, and available airline seat km/week, millions. It } \\
\text { ranges from } 1 \text { (extremely poor) to } 7 \text { (extremely good). }\end{array}$ & $\begin{array}{l}\text { Global } \\
\text { Competitiveness } \\
\text { Index dataset, World } \\
\text { Economic Forum }\end{array}$ \\
\hline $\begin{array}{l}\text { Electricity } \\
\text { and telephony } \\
\text { infrastructure }\end{array}$ & $\begin{array}{l}\text { Index measuring the quality of electricity supply, the number } \\
\text { of fixed-telephone lines per } 100 \text { population, and the number } \\
\text { of mobile telephone subscriptions per } 100 \text { population. It } \\
\text { ranges from } 1 \text { (extremely unreliable) to } 7 \text { (extremely reliable). }\end{array}$ & $\begin{array}{l}\text { Global } \\
\text { Competitiveness } \\
\text { Index dataset, World } \\
\text { Economic Forum }\end{array}$ \\
\hline ICT use & $\begin{array}{l}\text { Index comprising the following: internet users (\%), fixed } \\
\text { broadband internet subscriptions per } 100 \text { population, } \\
\text { international internet bandwidth (kb/s) per user, mobile } \\
\text { broadband subscriptions per } 100 \text { population. It ranges from } 1 \\
\text { (lowest) to } 7 \text { (highest). }\end{array}$ & $\begin{array}{l}\text { Global } \\
\text { Competitiveness } \\
\text { Index dataset, World } \\
\text { Economic Forum }\end{array}$ \\
\hline \multicolumn{3}{|c|}{ Sub-index 3. Labor force quality } \\
\hline $\begin{array}{l}\text { Tertiary } \\
\text { education } \\
\text { enrolment } \\
\text { rate }\end{array}$ & $\begin{array}{l}\text { The ratio of total tertiary enrolment, regardless of age, to the } \\
\text { population of the age group that officially corresponds to the } \\
\text { tertiary education level. }\end{array}$ & $\begin{array}{l}\text { Global } \\
\text { Competitiveness } \\
\text { Index dataset, World } \\
\text { Economic Forum }\end{array}$ \\
\hline $\begin{array}{l}\text { Quality of } \\
\text { the education } \\
\text { system }\end{array}$ & $\begin{array}{l}\text { Index measuring how well the education system meets the } \\
\text { needs of a competitive economy. It ranges from } 1 \text { (not well at } \\
\text { all) to } 7 \text { (extremely well). }\end{array}$ & $\begin{array}{l}\text { Global } \\
\text { Competitiveness } \\
\text { Index dataset, World } \\
\text { Economic Forum }\end{array}$ \\
\hline $\begin{array}{l}\text { Quality of } \\
\text { scientific } \\
\text { research } \\
\text { institutions }\end{array}$ & $\begin{array}{l}\text { Index assessing the quality of scientific research institutions. } \\
\text { It ranges from } 1 \text { (extremely poor) to } 7 \text { (extremely good). }\end{array}$ & $\begin{array}{l}\text { Global } \\
\text { Competitiveness } \\
\text { Index dataset, World } \\
\text { Economic Forum }\end{array}$ \\
\hline $\begin{array}{l}\text { University- } \\
\text { industry } \\
\text { collaboration } \\
\text { in R\&D }\end{array}$ & $\begin{array}{l}\text { Index measuring the extent to which businesses and } \\
\text { universities collaborate on R\&D. It ranges from } 1 \text { (do not } \\
\text { collaborate at all) to } 7 \text { (collaborate extensively). }\end{array}$ & $\begin{array}{l}\text { Global } \\
\text { Competitiveness } \\
\text { Index dataset, World } \\
\text { Economic Forum }\end{array}$ \\
\hline \multicolumn{3}{|c|}{ Sub-index 4. Cost competitiveness } \\
\hline $\begin{array}{l}\text { Corporate } \\
\text { income tax }\end{array}$ & $\begin{array}{l}\text { Direct tax that applies to profits generated from conducting } \\
\text { a business. }\end{array}$ & $\begin{array}{l}\text { Eurostat for EU } \\
\text { members, Doing } \\
\text { Business reports for } \\
\text { non-EU members }\end{array}$ \\
\hline $\begin{array}{l}\text { Labor tax and } \\
\text { contributions }\end{array}$ & $\begin{array}{l}\text { The amount of taxes and mandatory contributions on labor } \\
\text { paid by the business, measured as percent of commercial } \\
\text { profits. }\end{array}$ & $\begin{array}{l}\text { World Development } \\
\text { Indicators }\end{array}$ \\
\hline $\begin{array}{l}\text { Gross average } \\
\text { monthly } \\
\text { wages }\end{array}$ & $\begin{array}{l}\text { Total wages and salaries in cash and in kind, before any tax } \\
\text { deduction and before social security contributions (expressed } \\
\text { in USD). }\end{array}$ & $\begin{array}{l}\text { United Nations } \\
\text { Economic } \\
\text { Commission for } \\
\text { Europe }\end{array}$ \\
\hline
\end{tabular}

Source: Author's compilation. 
Since the variables used to construct the FDI attractiveness index are scaled differently, it is necessary to normalize all data points to a common scale before aggregating them. Rescaling is one of the most commonly used methods for data normalization because of its desirable characteristics when the data are aggregated (Ebert \& Welsch, 2004). In particular, rescaling can widen the range of variables lying within small intervals and facilitate interpretation. To normalize each variable, the following formula is used:

$$
\mathbf{X}^{\prime}=\frac{\mathbf{X}-\min (\mathbf{X})}{\max (\mathbf{X})-\min (\mathbf{X})}
$$

where $\mathbf{X}^{\prime}$ is the normalized value and $\mathrm{X}$ is the original value. Rescaling normalizes variables to an identical range by linear transformation. All variables are converted to a scale from 0 to 1 , where 0 represents the worst score and 1 represents the best score.

Another necessary step in composing the FDI attractiveness index is consistency analysis. One of the most common estimates of the internal consistency in a set of sub-indicators is Cronbach's alpha (Nardo et al., 2005). It measures how well sub-indicators describe a unidimensional construct. Cronbach's alpha is zero if no correlation exists and the sub-indicators are independent. If the underlying items are perfectly correlated, it is equal to one. Therefore, a high Cronbach's alpha is an indication that the underlying items assess the desired indicator well. According to Hair, Black, Babin, and Anderson (2010), values of 0.60 to 0.70 are considered the lower limit of acceptability. As seen in Table 2, Cronbach's alphas for all sub-indices are above the acceptable threshold, which suggests that the chosen variables for each sub-index describe that index well.

In the next step, data are aggregated to calculate the four sub-indices and the composite FDI index. As noted by Nardo et al. (2005), most composite indicators rely on equal weighting, i.e., all variables are given the same weight. Hence, the four sub-indices are calculated by taking the averages of the respective variables, 
using equal weights. Then, the composite FDI attractiveness index is calculated as a weighted average of the four sub-indices, again using equal weights.

Table 2: Consistency Analysis

\begin{tabular}{l|c|c}
\hline \multirow{2}{*}{ Sub-index } & \multicolumn{2}{|c}{ Cronbach's alpha } \\
\cline { 2 - 3 } & 2013 & 2017 \\
\hline Institutional framework & 0.77 & 0.86 \\
\hline Infrastructure endowment & 0.81 & 0.89 \\
\hline Labor force quality & 0.75 & 0.82 \\
Cost competitiveness & 0.71 & 0.66 \\
\hline
\end{tabular}

Source: Author's calculations.

In the final step, to test the explanatory power of the FDI attractiveness index, we calculate the correlation between this index and inward FDI stock per capita. A positive and significant correlation between them would suggest good quality of the FDI index, since higher FDI attractiveness of a host country is expected to be associated with larger FDI stock per capita.

\section{Results}

Based on the approach described above, the four sub-indices of the FDI attractiveness index are calculated. The results from countries' performance on each sub-index are described separately. After that, countries' ranking in terms of the FDI attractiveness index is presented.

\subsection{Institutional Framework}

According to the results, Estonia is the best performing country in terms of institutional framework in both 2013 and 2017. This is due to its highest levels of investment freedom and property rights protection, as well as its low corruption level. Moreover, as seen in Figure 4, the score of Estonia on the institutional 
framework sub-index is significantly higher (0.97 in 2017) than the scores of the next countries in the ranking (Latvia 0.68, Slovenia 0.68, and Lithuania 0.64). The country with the least favorable institutional framework in both 2013 and 2017 is Bosnia and Herzegovina. This is due to acute problems such as weak property rights protection, widespread corruption, and burdensome entrepreneurial environment. Another SEE country - Serbia - has the second lowest score (0.24) on this indicator, which reflects the need for deep institutional reforms to tackle bureaucracy, reduce corruption, and improve property rights protection.

Figure 4: Sub-index "Institutional Framework", 2017

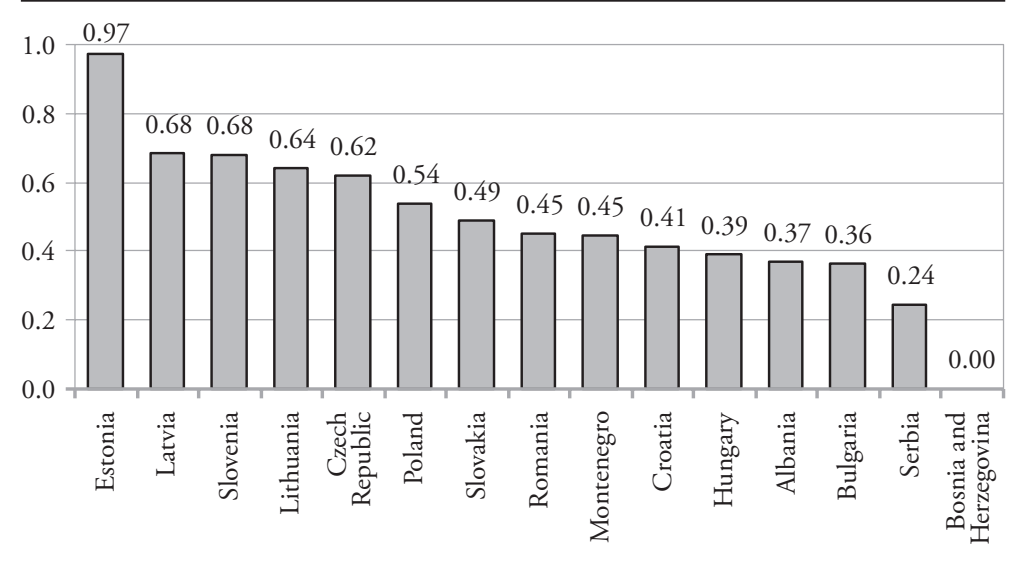

Source: Author's calculations.

The two countries which have moved up the most in terms of institutional environment (both by three places) between 2013 and 2017 are Latvia and Montenegro (Figure 5). In the case of Latvia, this was due to improvements in business freedom, property rights protection, and corruption perception. Montenegro improved its position in the ranking due to a more favorable regulatory environment for doing business and making investments. In contrast, the country that has moved down the most in the ranking is Hungary (from 3rd place in 2013 to 11 th place in 2017). This was due to worsening of the country's 
performance in areas such as business freedom, property rights protection, and corruption, both internally and relative to other countries.

Figure 5: Changes in the Institutional Framework, 2013 to 2017

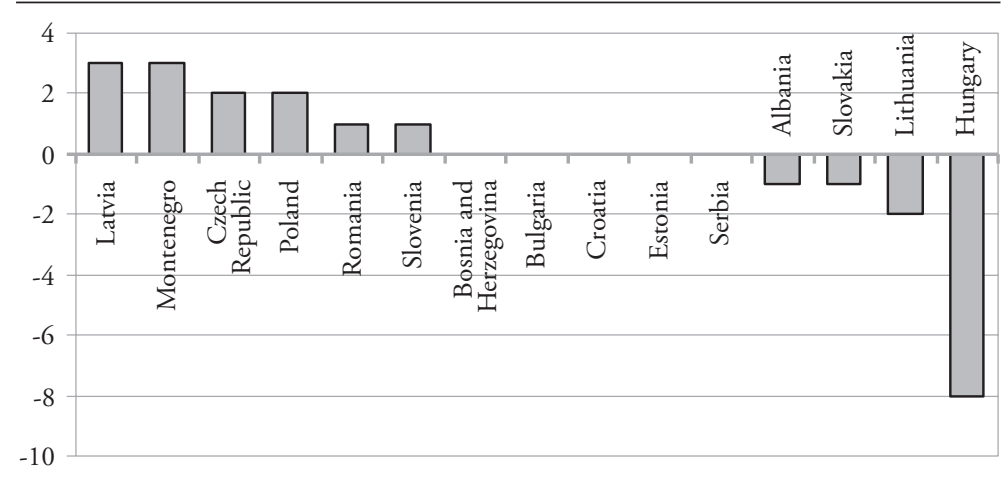

$\square$ Change in rank (2013-2017)

Source: Author's calculations.

\subsection{Infrastructure Endowment}

As seen in Figure 6, the country with the highest score on overall infrastructure endowment in 2017 is Estonia (0.99). It ranks first in terms of ICT and transport infrastructure and second (after Slovenia) with regard to electricity and telephony infrastructure. The next country in the ranking is Slovenia (0.81), closely followed by Lithuania (0.78), Croatia (0.76), and the Czech Republic (0.74). The countries with the lowest scores on infrastructure endowment both in 2013 and 2017 are Bosnia and Herzegovina and Albania. Moreover, there is a significant gap in terms of the quality of infrastructure between these two countries and the average for the CESEE region. The deficiencies in infrastructure are indeed considered to be among the key problematic factors for business in both economies according to recent IMF country reports. 
Figure 6: Sub-index "Infrastructure Endowment", 2017

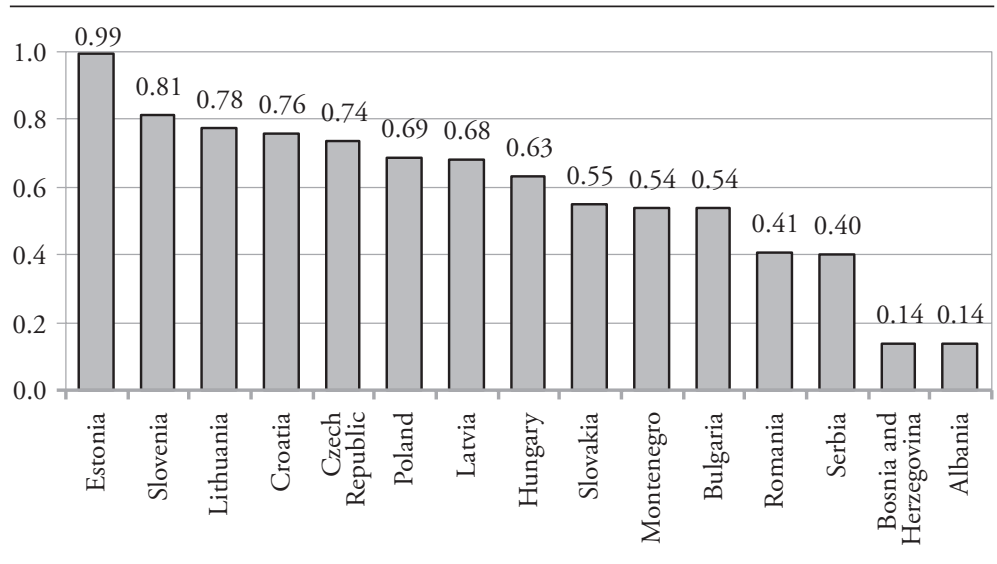

Source: Author's calculations.

Figure 7: Changes in the Infrastructure Endowment, 2013 to 2017

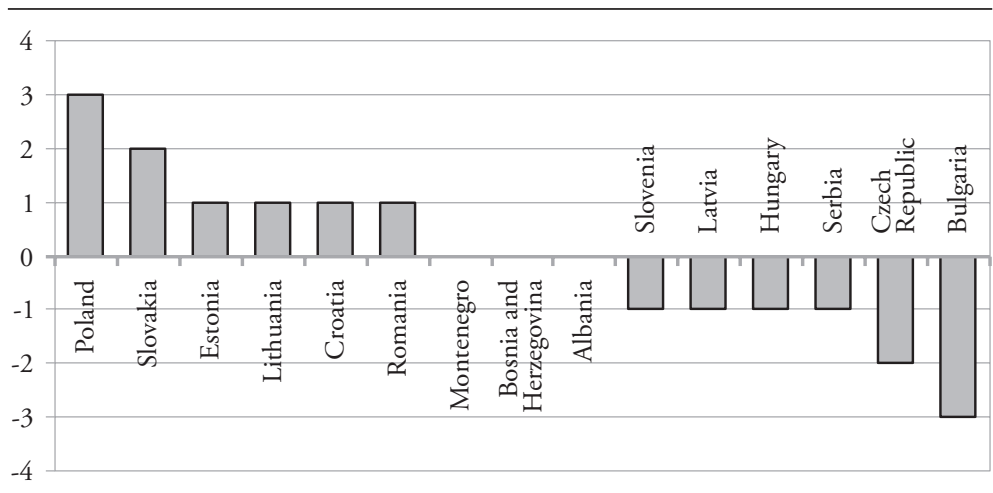

$\square$ Change in rank (2013-2017)

Source: Author's calculations.

With regard to the changes in countries' relative performance on infrastructure endowment over time, Poland has moved up the most in the ranking - from 9th 
place in 2013 to 6th place in 2017 (Figure 7). On the other hand, Bulgaria has fallen the most in the ranking (from 8th to 11 th place). However, this was due only to worsening of Bulgaria's performance relative to other countries and not to deterioration of the quality of infrastructure within the country itself.

\subsection{Labor Force Quality}

As with the previous two indicators, Estonia is the best performing country in terms of labor force quality in 2017, with a score of 0.87 (Figure 8). It ranks first in quality of the education system and quality of scientific research institutions, second in university-industry collaboration in R\&D (after Lithuania), and third in tertiary education enrolment (after Slovenia and Bulgaria). In the ranking of labor force quality, Estonia is followed by Slovenia (0.84), the Czech Republic (0.71), and Lithuania (0.70).

Figure 8: Sub-index "Labor Force Quality"

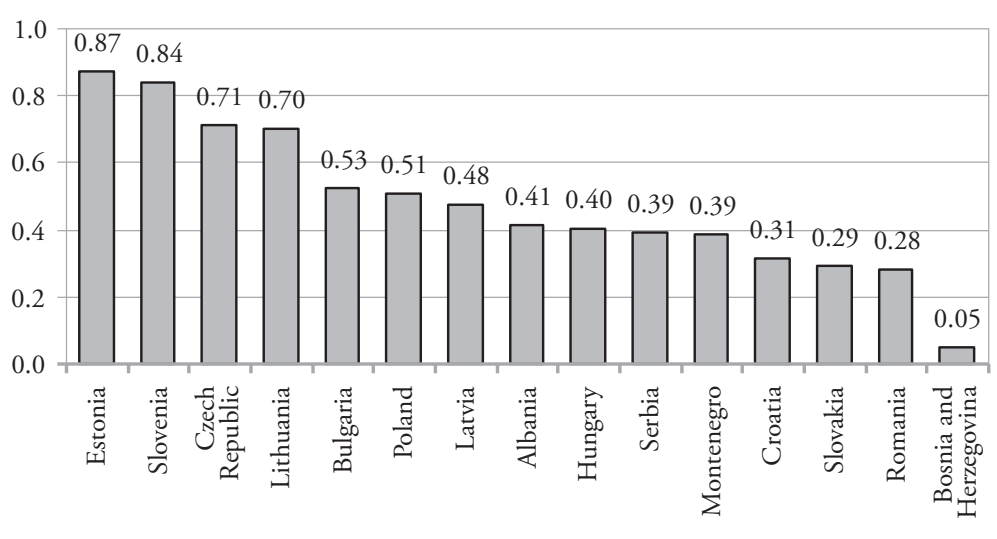

Source: Author's calculations.

The worst performing country in terms of labor force quality in 2017 is Bosnia and Herzegovina, with a score of just 0.05. Moreover, as shown in Figure 9, the 
country experienced a fall in its position in the ranking by three places between 2013 and 2017. The country which moved down the most in the ranking (by five places) is Montenegro. This is due to worsening of the country's performance itself, as well as relative to other countries in terms of quality of the education system and the scientific research institutions, as well as the collaboration in R\&D between universities and industry.

Figure 9: Changes in Labor Force Quality, 2013 to 2017

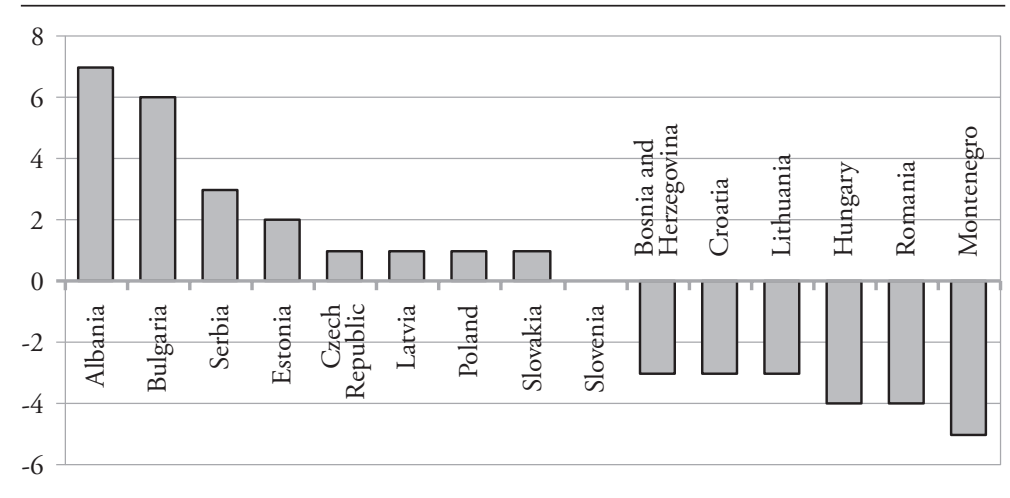

$\square$ Change in rank (2013-2017)

Source: Author's calculations.

The country which has risen the most in terms of labor force quality is Albania (from 15th place in 2013 to 8 th place in 2017). This is a result of improvements in tertiary education enrolment, the quality of the education system, and especially the university-industry collaboration in R\&D. The country with the second highest increase in the ranking is Bulgaria, which has moved up six places due to a significant rise in tertiary education enrolment, strengthening of the collaboration in R\&D between universities and industry, as well as improvement in the quality of scientific research institutions. However, it is worth noting that while the relative quality of the education system in Bulgaria has not changed, the performance of the country itself has slightly worsened. Improving the quality of 
education and mitigating the substantial skill mismatches are indeed some of the biggest challenges for Bulgaria's public policy.

\subsection{Cost Competitiveness}

With regard to cost competitiveness, SEE countries perform better than CEE and Baltic countries. This is due to the combination of relatively lower corporate taxes and labor tax and contributions, as well as greater wage competitiveness of the SEE economies. As shown in Figure 10, Montenegro achieved the highest score in 2017 (0.90), closely followed by Bosnia and Herzegovina (0.89) and Bulgaria (0.85). The worst performer in terms of cost competitiveness is Slovakia (0.17), followed by Estonia (0.19) and the Czech Republic (0.24). This can be explained by the relatively higher levels of corporate taxes, labor tax and contributions, and wages in these countries.

Figure 10: Sub-index "Cost Competitiveness", 2017

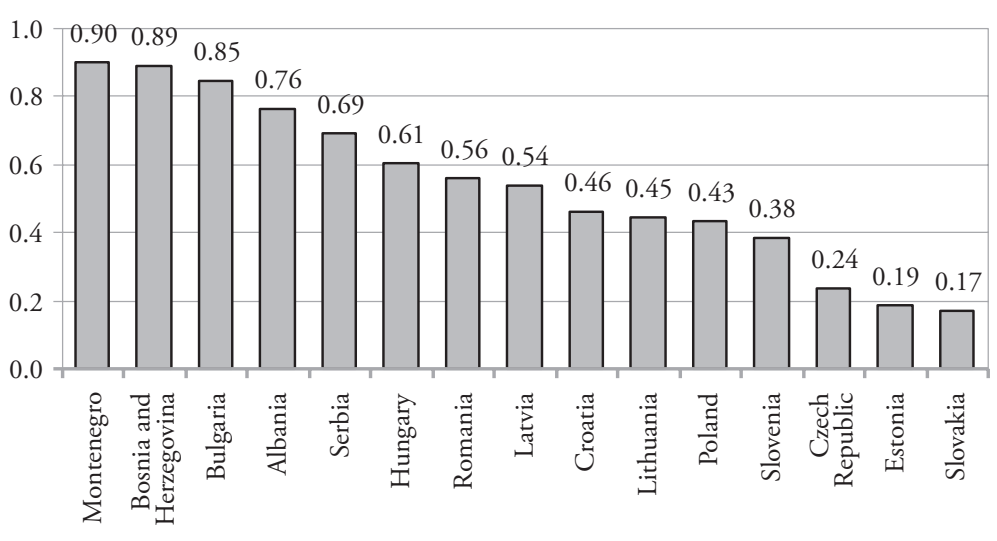

Source: Author's calculations.

The country with the highest improvement in its position in the ranking of cost competitiveness is Hungary, which moved up six places from 2013 to 2017 
(Figure 11). This is largely due to the reduction of the corporate tax rate from 19 percent to 9 percent in 2017, which makes Hungary the country with the lowest corporate tax rate in the CESEE region (along with Montenegro, where corporate tax rate is also 9 percent). The country that has fallen the most in terms of cost competitiveness is Albania. It moved from 1st place in 2013 to 4th place in 2017, which is due to an increase in the corporate tax rate from 10 percent to 15 percent in 2014.

Figure 11: Changes in Cost Competitiveness, 2013 to 2017

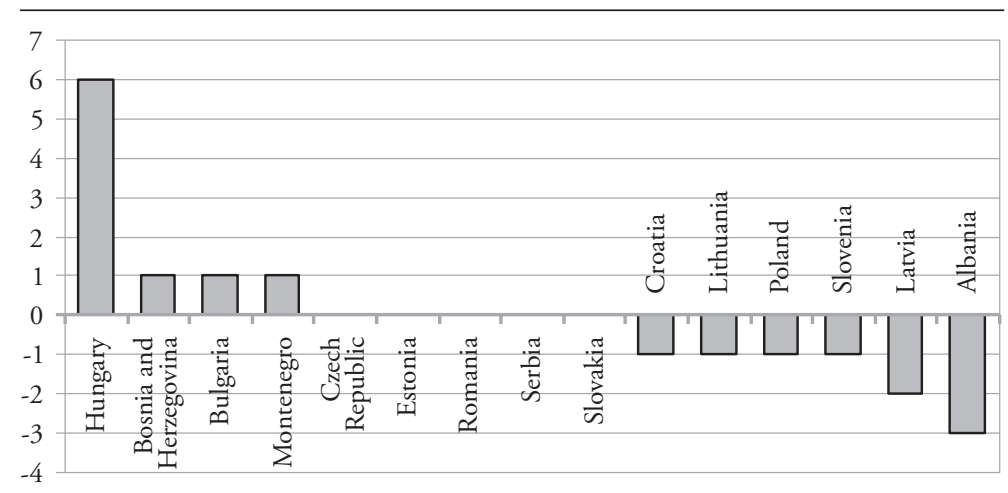

$\square$ Change in rank (2013-2017)

Source: Author's calculations.

\subsection{Composite FDI Attractiveness Index}

The results from the calculation of the FDI attractiveness index show that Estonia is the most attractive country in the CESEE region with a score of 0.76 in 2017 (Figure 12). As shown in the previous paragraphs, Estonia's top performance is due to its highest scores in areas such as institutional framework, infrastructure endowment, and labor force quality. Next in the ranking are Slovenia and Lithuania, with scores of 0.68 and 0.64 , respectively. 
Figure 12: Composite FDI Attractiveness Index, 2017

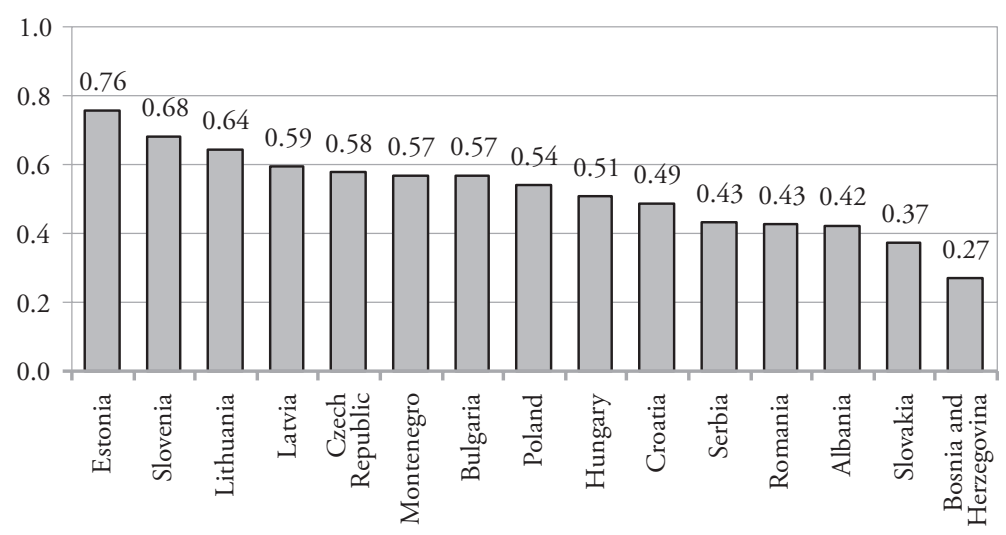

Source: Author's calculations.

The country with the lowest FDI attractiveness index (0.27 in 2017) is Bosnia and Herzegovina. Its weak performance in the ranking is explained by the pronounced deficiencies in the quality of institutions, infrastructure, and labor force, which outweigh the country's high cost competitiveness. Moreover, as seen in Figure 13, Bosnia and Herzegovina has moved down the most in ranking - from 12th place in 2013 to 15 th place in 2017 . This is due to the deterioration of the country's performance in all areas except cost competitiveness.

The country with the highest improvement in its position in the ranking of FDI attractiveness is Bulgaria, which has moved up three places from 2013 to 2017. This is due to an increase in the sub-index measuring labor force quality, as well as to a slight improvement in the country's relative cost competitiveness. At the same time, Bulgaria experienced worsening of its relative position in terms of infrastructure endowment, as well as lack of progress in its relative institutional quality. 
Figure 13: Changes in FDI Attractiveness of CESEE Countries, 2013 to 2017

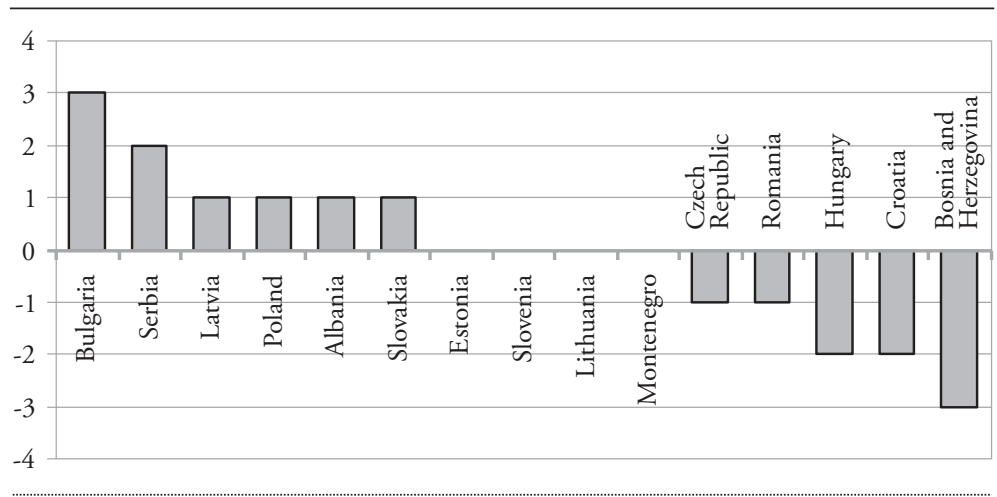

Source: Author's calculations.

To examine the explanatory power of the FDI index, a comparison is made between the rankings of countries in terms of the FDI index and inward FDI stock per capita in 2017. As Figure 14 shows, Estonia is the leader in terms of both the FDI attractiveness index and inward FDI stock per capita. The two rankings correspond also for Montenegro. For nine other countries there are differences of up to three places. However, there are four countries with more pronounced mismatches between the two rankings, namely Slovenia, Lithuania, Hungary, and Slovakia. This suggests that there could be other important determinants of FDI, not captured in the index, such as location, macroeconomic fundamentals, political stability, or the provision of financial incentives to foreign investors. This could be the case for Slovakia and Hungary, which are geographically closer to Western Europe, have GDP per capita above the CESEE average, and have treated FDI (especially Hungary) as a key element in their market transition. This could explain their higher position in the ranking according to the accumulated FDI stock per capita. Conversely, Slovenia’s policy towards FDI has been relatively passive, even aversive, during the first decade of market transition, which could 
be reflected in the lower level of foreign capital penetration despite the country's high level of investment attractiveness.

Figure 14: Rankings According to FDI Attractiveness Index and FDI Stock per Capita

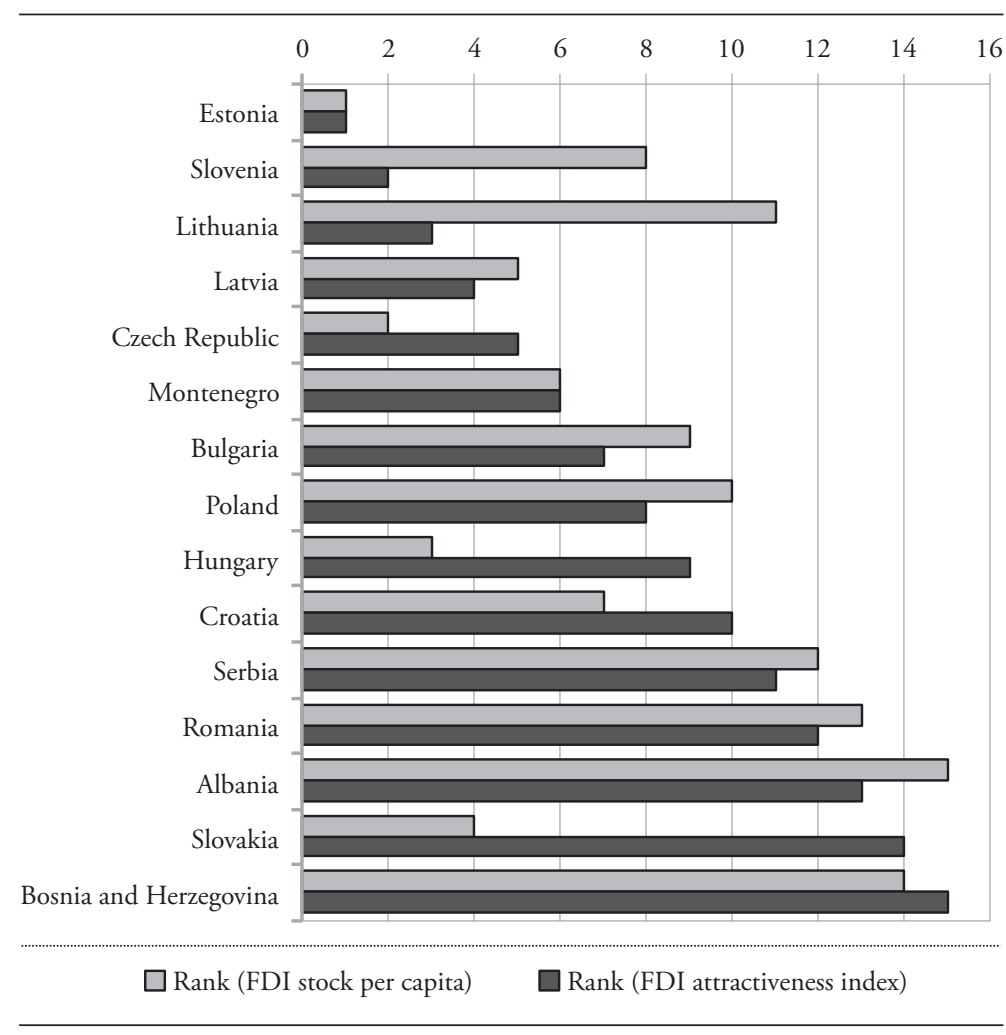

Source: Author's calculations.

To further test the explanatory properties of the FDI attractiveness index, the correlation between this index and the log value of inward FDI stock per capita is calculated. 
Table 3: Correlation between FDI Attractiveness Index and FDI Stock per Capita

\begin{tabular}{l|c|c}
\hline Index & Correlation coefficient & p-value \\
\hline FDI attractiveness index $(2013)$ & 0.55 & 0.03 \\
\hline FDI attractiveness index $(2017)$ & 0.69 & 0.00 \\
\hline
\end{tabular}

Source: Author's calculations.

As seen in Table 3, the correlation coefficients for both 2013 and 2017 are positive and significant. This suggests that greater FDI attractiveness, measured in terms of the composite index, is associated with larger FDI stock per capita in the host country. Since all variables used to construct the FDI attractiveness index are policy-related, it can be argued that there is a great scope for public policy to influence the FDI attractiveness of CESEE countries, by shaping their institutions, infrastructure, labor force quality, and cost competitiveness.

\section{Conclusion}

The paper explores FDI attractiveness of 15 CESEE countries by constructing a composite FDI index for 2013 and 2017. It allows the comparison of countries' performance on four key dimensions - institutional framework, infrastructure endowment, labor force quality, and cost competitiveness. These have been outlined in previous studies as crucial aspects of a host country's investment climate and are also under the influence of public policy.

Based on the results from the calculation of the FDI attractiveness index, the following conclusions can be drawn. First, Estonia is the best performing country in terms of quality of institutions, infrastructure, and labor force, which makes the country the most attractive FDI destination according to the composite FDI index in both 2013 and 2017. Moreover, the comparison with the ranking in terms of the accumulated FDI revealed that Estonia has indeed attracted the largest FDI stock per capita. Second, Bosnia and Herzegovina is the worst performing country in all aspects of FDI attractiveness except for cost competitiveness, which 
makes the country occupy the last position according to the composite FDI index in 2017. Overall, SEE countries have higher scores on cost competitiveness than CEE economies, but this cannot compensate the deficiencies in important areas such as institutional framework (in Bosnia and Herzegovina and Serbia), infrastructure (in Albania and Bosnia and Herzegovina), and labor force quality (Bosnia and Herzegovina). Because of the latter, the SEE countries (with the exception of Montenegro) have lower scores on the FDI attractiveness index than most CEE countries and have also received smaller amounts of FDI stock per capita.

The results from the analysis lead to some important policy implications. Since public policy can strongly shape FDI attractiveness of a host country, there is a need and room for improvement of the institutional framework, the infrastructure, and the labor force quality in many countries in the CESEE region - most SEE countries, as well as some of the new EU members such as Bulgaria and Romania. This would create favorable conditions not only for FDI attraction, but also for economic growth.

The analysis has faced several limitations with regard to data availability. First, due to lack of data for all variables for North Macedonia, it was not included among the SEE countries. Second, financial incentives provided to foreign investors, as well as activities of investment promotion agencies, can strongly impact FDI attractiveness, but due to lack of data, they are not captured by the FDI index. Third, some of the variables used to calculate the FDI index are ready-made indices (for example those from the Global Competitiveness Report), which have been computed based on survey data. Although there might be possible bias in this type of data, due to lack of other appropriate measures, the analysis has used such indices to account for some of the dimensions of the FDI index. Given the importance of FDI for the development of CESEE economies, future research might utilize data with better quality and country coverage and explore the determinants of FDI in this region. 


\section{Literature}

Altomonte, C. (2000). Economic determinants and institutional frameworks: FDI in economies in transition. Transnational Corporations, 9(2), 75-106. Retrieved from: http://citeseerx.ist.psu.edu/viewdoc/download?doi=10.1.1.471. $4684 \&$ rep $=$ rep $1 \&$ type $=$ pdf $\#$ page $=81$

Bellak, C., Leibrecht, M., \& Damijan, J. (2009). Infrastructure endowment and corporate income taxes as determinants of foreign direct investment in Central and Eastern European countries. The World Economy, 32(2), 267-290. doi: https://doi.org/10.1111/j.1467-9701.2008.01144.x

Bellak, C., Leibrecht, M., \& Liebensteiner, M. (2010). Attracting foreign direct investment: The public policy scope for South East European countries. Eastern Journal of European Studies, 1(2), 37-53. Retrieved from: http://ejes.uaic.ro/ articles/EJES2010_0102_BEL.pdf

Bellak, C., Leibrecht, M., \& Riedl, A. (2008). Labour costs and FDI flows into Central and Eastern European countries: A survey of the literature and empirical evidence. Structural Change and Economic Dynamics, 19(1), 17-37. doi: https:// doi.org/10.1016/j.strueco.2007.03.001

Bellak, C., Leibrecht, M., \& Stehrer, R. (2010). The role of public policy in closing foreign direct investment gaps: An empirical analysis. Empirica, 37(1), 19-46. doi: https://doi.org/10.1007/s10663-009-9107-6

Bevan, A., \& Estrin, S. (2004). The determinants of foreign direct investment into European transition economies. Journal of Comparative Economics, 32(4), 775-787. doi: https://doi.org/10.1016/j.jce.2004.08.006

Bevan, A., Estrin, S., \& Meyer, K. (2004). Foreign investment location and institutional development in transition economies. International Business Review, 13(1), 43-64. doi: https://doi.org/10.1016/j.ibusrev.2003.05.005

Botrić, V., \& Škuflić, L. (2006). Main determinants of foreign direct investment in the Southeast European countries. Transition Studies Review, 13(2), 359-377. doi: https://doi.org/10.1007/s11300-006-0110-3 
Brahim, M., \& Dupuch, S. (2016). Foreign direct investments in Europe: Are the East-West differences still so noticeable? The European Journal of Comparative Economics, 13(1), 37-61. Retrieved from: http://ejce.liuc.it/18242979201601/1 82429792016130102.pdf

Cantwell, J. (2009). Location and the multinational enterprise. Journal of International Business Studies, 40, 35-41. doi: https://doi.org/10.1057/ jibs.2008.82

Carstensen, K., \& Toubal, F. (2004). Foreign direct investment in Central and Eastern European countries: A dynamic panel analysis. Journal of Comparative Economics, 32(1), 3-22. doi: https://doi.org/10.1016/j.jce.2003.11.001

Copenhagen Economics. (2016). Towards an FDI Attractiveness Scoreboard. Brussels: European Commission, Directorate-General for Internal Market, Industry, Entrepreneurship and SMEs. Retrieved from: https://publications. europa.eu/en/publication-detail/-/publication/798752f0-3138-11e6-b49701aa75ed71a1

Corruption Perceptions Index, Transparency International. Retrieved from: https://www.transparency.org/cpi2019

Dacin, M. T., Goldstein, J., \& Scott, W. R. (2002). Institutional theory and institutional change: Introduction to the special research forum. Academy of Management Journal, 45(1), 45-57. Retrieved from: https://www.jstor.org/ stable/3069284

Dauti, B. (2015). Determinants of foreign direct investment in South East European countries and new member states of European Union countries. Economic and Business Review, 17(1), 93-115. Retrieved from: http://ojs. ebrjournal.net/ojs/index.php/ebr/article/view/373

Dunning, J. H. (1979). Explaining changing patterns of international production: In support of the eclectic theory. Oxford Bulletin of Economics and Statistics, 41(4), 269-295. doi: https://doi.org/10.1111/j.1468-0084.1979.mp41004003.x 
Dunning, J. H. (1981). International production and the multinational enterprise. London: George Allen \& Unwin.

Dunning, J. H. (1988). Explaining international production. London: Unwin Hyman. doi: https://doi.org/10.4324/9781315739250

Dunning, J. H. (1993a). The globalization of business. London and New York: Routledge.

Dunning, J. H. (1993b). Multinational enterprises and the global economy. Wokingham: Addison-Wesley Publishing Company.

Dunning, J. H. (1997). The European internal market program and inbound foreign direct investment. Journal of Common Market Studies, 35(1), 1-30 and 35(2), 189-223. doi: https://doi.org/10.1111/j.1468-5965.1996.tb00593.x

Dunning, J. H. (2009). Location and the multinational enterprise: A neglected factor. Journal of International Business Studies, 40(1), 5-19. Retrieved from: https://www.jstor.org/stable/25483356

Dunning, J. H., \& Lundan, S. (2008a). Institutions and the OLI paradigm of the multinational enterprise. Asia Pacific Journal of Management, 25(4), 573-593. doi: http://dx.doi.org/10.1007/s10490-007-9074-z

Dunning, J. H., \& Lundan, S. (2008b). Multinational enterprises and the global economy [ $2^{\text {nd }}$ edition]. Cheltenham: Edward Elgar. Retrieved from: http://www.eelgar.com/shop/isbn/9781843765257

Ebert, U., \& Welsch, H. (2004). Meaningful environmental indices: A social choice approach. Journal of Environmental Economics and Management, 47(2), 270-283. doi: https://doi.org/10.1016/j.jeem.2003.09.001

Eden, L. (2003). A critical reflection and some conclusions on OLI. In J. Cantwell \& R. Narula (Eds.) International business and the eclectic paradigm: Developing the OLI framework (pp. 277-297). London: Routledge. doi: https:// doi.org/10.4324/9780203576427 
Estrin, S., \& Uvalic, M. (2014). FDI into transition economies: Are the Balkans different? Economics of Transition, 22(2), 281-312. doi: https://doi.org/10.1111/ ecot. 12040

Eurostat database. Retrieved from: https://ec.europa.eu/taxation_customs/ business/economic-analysis-taxation/data-taxation_en

Fabry, N., \& Zeghni, S. (2010). Inward FDI in seven transitional countries of South-Eastern Europe: A quest of institution-based attractiveness. Eastern Journal of European Studies, 1(2), 77-91. Retrieved from: http://ejes.uaic.ro/articles/ EJES2010_0102_FAB.pdf

Faeth, I. (2009). Determinants of foreign direct investment - a tale of nine theoretical models. Journal of Economic Surveys, 23(1), 165-196. doi: https://doi. org/10.1111/j.1467-6419.2008.00560.x

Global Competitiveness Index dataset, World Economic Forum. Retrieved from: http://reports.weforum.org/global-competitiveness-index-2017-2018/ downloads/

Groh, A., \& Wich, M. (2012). Emerging economies' attraction of foreign direct investment. Emerging Markets Review, 13(2), 210-229. doi: https://doi. org/10.1016/j.ememar.2012.03.005

Günther, J., \& Kristalova, M. (2016). No risk, no fun? Foreign direct investment in Central and Eastern Europe. Intereconomics, 51(2), 95-99. doi: https://doi. org/10.1007/s10272-016-0583-1

Hair, J. F., Black, W. C., Babin, B. J., \& Anderson, R. E. (2010). Multivariate data analysis $\left[7^{\text {th }}\right.$ edition]. Upper Saddle River, NJ: Pearson Education.

Holland, D., Sass, M., Benacek, V., \& Gronicki, M. (2000). The determinants and impact of FDI in Central and Eastern Europe: A comparison of survey and econometric evidence. Transnational Corporations, 9(3), 163-212. Retrieved from: http://pure.iiasa.ac.at/id/eprint/5953/1/iteiit21v9n3_en.pdf

Index of Economic Freedom, Heritage Foundation. Retrieved from: https://www. heritage.org/index/ 
Kalotay, K. (2010). Patterns of inward FDI in economies in transition. Eastern Journal of European Studies, 1(2), 55-76. Retrieved from: http://ejes.uaic.ro/ articles/EJES2010_0102_KAL.pdf

Leibrecht, M., \& Riedl, A. (2014). Modelling FDI based on a spatially augmented gravity model: Evidence for Central and Eastern European countries. The Journal of International Trade \& Economic Development, 23(8), 1206-1237. doi: https:// doi.org/10.1080/09638199.2013.861006

Mateev, M. (2009). Determinants of foreign direct investment in Central and Southeastern Europe: New empirical tests. Oxford Journal, Special Issue, 8(1), 133-149. Retrieved from: http://mateevfinance. com/infoArticle.php?id=215

Mateev, M., \& Tsekov, I. (2014). Are there any top FDI performers among EU-15 and CEE countries? A comparative panel data analysis. Financial Theory and Practice, 38(3), 337-374. Retrieved from: http://fintp.ijf.hr/upload/files/ $\mathrm{ftp} / 2014 / 3 /$ mateev_tsekov.pdf

Nardo, M., Saisana, M., Saltelli, A., Tarantola, S., Hoffman, A., \& Giovannini, E. (2005). Handbook on constructing composite indicators: Methodology and user guide. OECD Statistics Working Paper No. 2005/3. doi: https://doi. org/10.1787/533411815016

Narula, R. (2010). Keeping the eclectic paradigm simple. Multinational Business Review, 18(2), 35-50. doi: https://doi.org/10.1108/1525383X201000009

Narula, R., \& Dunning, J. H. (2000). Industrial development, globalization and multinational enterprises: New realities for developing countries. Oxford Development Studies, 28(2). 141-167. doi: https://doi.org/10.1080/713688313

North, D. (1990). Institutions, institutional change and economic performance. New York: Cambridge University Press. doi: https://doi.org/10.1017/ CBO9780511808678 
Peng, M. W., Wang, D. Y. L., \& Jiang, Y. (2008). An institution-based view of international business strategy: A focus on emerging economies. Journal of International Business Studies, 39(5), 920-936. doi: https://doi.org/10.1057/ palgrave.jibs. 8400377

Popovici, O. C., \& Călin, A. C. (2012). Attractiveness of public policies for FDI in Central and Eastern European countries. Annals of Faculty of Economics, University of Oradea, 1(1), 61-67. Retrieved from: https://ideas.repec.org/a/ora/ journl/v1y2012i1p61-67.html

Stack, M., Ravishankar, G., \& Pentecost, E. (2017). Foreign direct investment in the Eastern European countries: Determinants and performance. Structural Change and Economic Dynamics, 41, 86-97. doi: https://doi.org/10.1016/j. strueco.2017.04.005

Su, W., Zhang, D., Zhang, C., Abrhám, J., Simionescu, M., Yaroshevich, N., \& Guseva, V. (2018). Determinants of foreign direct investment in the Visegrad group countries after the EU enlargement. Technological and Economic Development of Economy, 24(5), 1955-1978. doi: https://doi.org/10.3846/tede.2018.5487

Tintin, C. (2013). The determinants of foreign direct investment inflows in the Central and Eastern European countries: The importance of institutions. Communist and Post-Communist Studies, 46(2), 287-298. doi: https://doi. org/10.1016/j.postcomstud.2013.03.006

UNCTAD Data Center. Retrieved from: https://unctadstat.unctad.org/EN/

United Nations Economic Commission for Europe, Statistical Database. Retrieved from: https://w3.unece.org/PXWeb/en

World Development Indicators, the World Bank. Retrieved from: http:// datatopics.worldbank.org/world-development-indicators/ 